\title{
The history of dermatology, venereology and dermatopathology in different countries - Turkey
}

\section{Prof. Ilgen Ertam*}

Department of Dermatology and Venereology, Ege University Faculty of Medicine, Izmir, Turkey

\section{History of Dermatology in Turkey}

Turkey is a Eurasian country located in Asia and Europe. Bulgaria, Greece, Georgia, Armenia, Azerbaijan, Iran, Iraq and Syria are border countries. The Mediterranean Sea is to the South, the Aegean Sea is to the West, and Black Sea is to the North. The Bosphorus and the Dardanelles separate Europe and Asia.

In our country, the first Medical School was established in March 14, 1827 without having a Dermatology Department. The training programme of this branch was carried out by faculty members of other departments. These lecturers were Assoc.Prof.Galiniçi from the Department of Internal Medicine, Nuri Kenan from the Department of Pharmacology and İlyas Matar from Ophtalmology. At the end of the 19th century, a syphilis outbreak had become one of theimportant problems in Turkey. Huseyin Hulki from the Department of Physiology pointed out the need of Dermatology Clinic. Van der Golt Pasha from Turkish Military also reported the syphilis outbreak in soldiers to Sultan Abdulhamid [1,2].

As a result of these warnings, a dermatologist was requested from Germany. Ernest von Düring was invited by the Ottoman Empire to found the dermatology department at the Royal Military School of Medicine. Modern dermatology in Turkey began with von Düring. His colleaque, Huseyin Hulki became Associate Professor in the Department of Dermatology at Istanbul Faculty of Medicine.

Celal Muhtar later served for 6 years as Chairman of the same department $[1,3]$. Therefore, it can be said that dermatology education in our country started after this year. In those years, Dr.Celal Muhtar completed his dermatology training in Paris and returned to our country in 1901. Dr. Celal Muhtar worked with such famous scientists as Fournier, Vidal, and Darier and attended courses at the Pasteur Institute. Dr.Hüseyin Hulki, Şükrü Mehmet, Eşref Ruşen, Naci Erim, Hasan Reşad, Ali Rıza Atasoy, Hüseyinzade Ali Turan and Ömer Abdurrahman were his assistants $[1,3]$.

Dr.Celal Muhtar had many publications about syphilis. He also described a disease, namely Trichophytie Palmaire et Plantaire. The disease is characterized by a form of Tricophytoses on both plantar and palmar areas, and the disease is referred to by his name in literatüre (Celallettin Muhtar's Disease). The moulages of this disease have been exhibited in Saint-Louis Hospital Museum [1,3] (Figure 1).

After resignation of Dr. Celal Muhtar in 1923, Hasan Resat Bey started to work in the Istanbul Darülfünun Medical Faculty. Dr. Hasan Resat Sigındım defined monocytic leukemia in 1913. This has been a source of pride for Turkish medicine. The name of Istanbul Darulfunun was changed to Istanbul University in 1933.
Hulusi Behcet (1890-1948) directed the Dermatology and Syphilis Clinic for 14 years [1]. Hulusi Behcet is a famous dermatologist. He completed his education at Gulhane Medical Academy in 1914. Dr.Behcet observed the symptoms in three patients for years. After the obervations of these patients, he concluded that they were the symptoms of a new disease in 1936 . He reported these cases in the Archives of Dermatology and Veneral Disease. Today, this disease is called Behcet's Disease in medical literature. He died from a sudden heart attack on March 8, 1948. [2].

Turkan Saylan (1935-2009) is an another famous dermatologist. She was an academician in Istanbul University Medical Academy. She was also a writer and social activist. She worked to eradicate leprosy

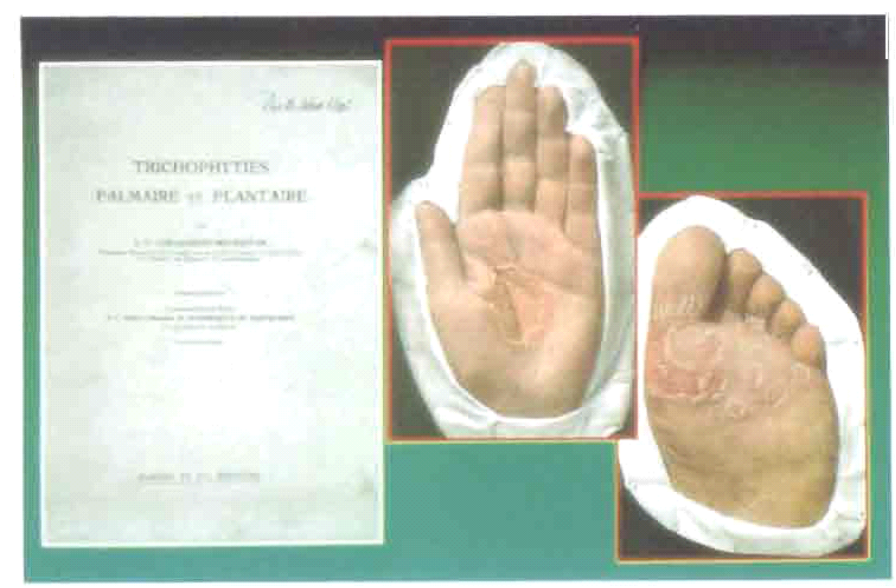

Figure 1. Wax models of tinea pedis et manuum [1]

Correspondence to: Prof. Dr. Ilgen Ertam, Department of Dermatology and Venereology, Ege University Faculty of Medicine, Izmir, Turkey, Tel: 90-232-390 38 31; 90-532-715 45 04; E-mail: ilgenertam@gmail.com

Special Issue: Dermatology History in Different Countries

Nooshin Bagherani, M. D.

Dermatologist at Dr. Nooshin Bagheran's office, Taha Physicians' building, P.O.Box: 6414715878, Khoramshahr, Khuzestan Province, Iran; Email: nooshinbagherani@yahoo.com

Bruce R. Smoller, M. D.

Chair, Department of Pathology and Laboratory Medicine Professor, Department of Pathology and Laboratory Medicine Professor, Department of Dermatology

University of Rochester School of Medicine and Dentistry, USA

E-mail: smollerbrucer@uams.edu

Published: December 20, 2015 


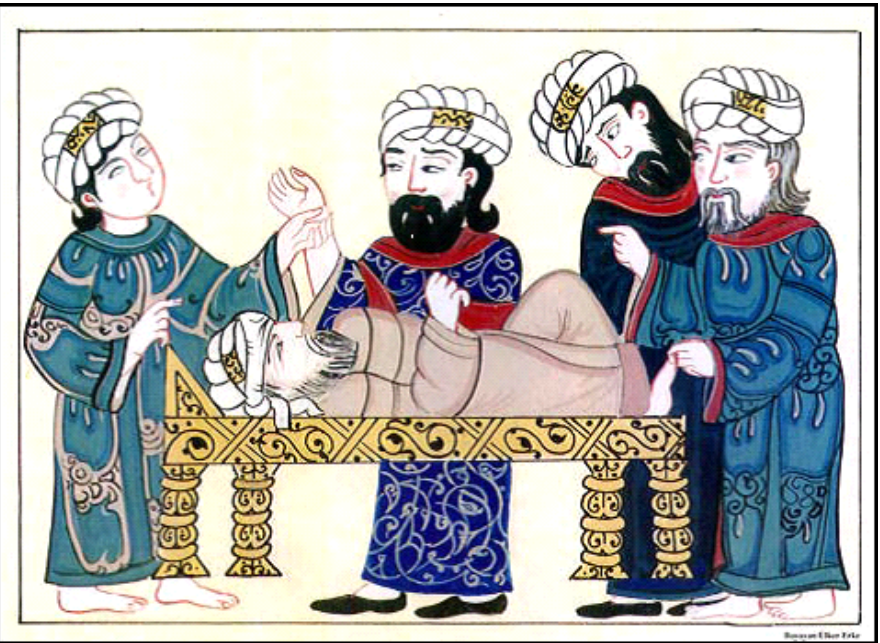

Figure 2. This miniature is a representation of a consultation among physicians [4].

and established a foundation called "Association for the Support of Contemporary Living” (Çağdaş Yaşamı Destekleme Derneği, ÇYDD). This Association provides scholarships for education of girls.

Iconagraphy is an interesting art branch. of which dermatology serves an application area. A collection composed of portraits, pictures, cartoons, wax moulds, and miniatures reflecting historical aspects of Turkish dermatology is exhibited in three museums in Istanbul University and Municipal Medical Center of Istanbul [4] (Figure 2).

Turkish Virtual Museum was established by Assoc.Prof. Adem Koslu. It is a unique museum and contains historical information of
Turkish Dermatology and dermatologists in virtual world (http://www. sanalmuzedermatoloji.net)

The Turkish Society of Dermatology is the main society in Turkey. Prof. Ertan Yllmaz is a president of the Turkish Society of Dermatology. There are 1655 dermatologists in Turkey in 2015. 798 of them are specialists, 90 of them Assoc. Professors and 168 of them Professors. There are several periodicals that have been published in our country about dermatology. Turkish Journal of Dermatology is the official journal of Turkish Society of Dermatology, Turkderm (Archieves of Turkish Dermatology and Venereology), Turkdem-Archives of the Turkish Dermatology and Venerology is the official journal of the Turkish Society of Dermatology and Venerology. Other journals in Turkey are Journal of the Turkish Academy of Dermatology, Turkiye Klinikleri Journal of Dermatology.

\section{Acknowledgement}

Thanks to Assoc. Prof. Adem Köşlü for invaluable support.

\section{References}

1. Koslu A (1993) Turk Dermatoloji Tarihi. Dermatoloji'de Gelişmeler-2. Tüzün Y, Serdaroğlu S, Aydemir EH. Istanbul: 54-67.

2. Ustün C (2002) A famous Turkish dermatologist, Dr. Hulusi Behçet. Eur J Dermatol 12: $469-470$.

3. Koslu A (2015) Sanal Turk Dermatoloji Müzesi Arşivi nasıl gelişti? Turk J Dermatol 1: $60-62$.

4. Tuzun Y (2007) Art in Turkish Dermatology. Journal of the Turkish Academy of Dermatology 1: 71201r.

5. Koslu A, Ekmekci TR (2006) German dermatologists and their contributions to Turkish dermatology. J Dtsch Dermatol Ges 4: 894-897.

Copyright: (C2015 Ertam I. This is an open-access article distributed under the terms of the Creative Commons Attribution License, which permits unrestricted use, distribution, and reproduction in any medium, provided the original author and source are credited. 